\title{
Correlation of P-wave Velocity with Rock Quality Designation (RQD) in Volcanic Rocks
}

\author{
Ainul Fatayaatis Salaamah ${ }^{1}$, Teuku Faisal Fathani*1,3 ${ }^{\text {, and Wahyu Wilopo }}$ 2,3 \\ ${ }^{1}$ Department of Civil and Environmental Engineering, Faculty of Engineering, Universitas Gadjah Mada, \\ Yogyakarta, Indonesia \\ ${ }^{2}$ Department of Geological Engineering, Faculty of Engineering, Universitas Gadjah Mada, Yogyakarta, Indonesia \\ ${ }^{3}$ Center for Disaster Mitigation and Technological Innovation (GAMA-InaTek), Universitas Gadjah Mada, \\ Yogyakarta, Indonesia
}

\begin{abstract}
One important part of rock mass investigation is the geomechanical assessment in terms of rock mass classification systems. Rock mass classification is one of the most efficient methods in rock mechanics to provide a basic understanding of rock mass characterization. Rock mass properties can be determined by a seismic refraction survey as an indirect geophysical assessment. In this study, the P-wave velocity from seismic refraction was compared with the Rock Quality Designation (RQD) from the boreholes. The empirical correlation between the RQD and the P-wave velocity was found by using the linear regression analysis. The RQD value estimated from the P-wave velocity can be applied for tropical environment study with geological conditions of volcanic rocks. This study helps to estimate and predict the subsurface rock quality, to reduce investigation costs, and to improve understanding of subsurface rock quality.
\end{abstract}

Keywords: Seismic refraction · Rockfill dam - Rock mechanic $\cdot$ Lithology · Geological mapping.

\section{INTRODUCTION}

Rock mass classification is used to provide a basis to understand the characteristics of rock mass class (Bieniawski, 1989). Some rock mass classifications commonly used are the Rock Quality Designation (Deere et al., 1967) which only considers the space of joints, the Q-system (Barton et al., 1974), and the Rock Mass Rating (Bieniawski, 1989). The Q-system and the Rock Mass Rating use RQD as the measurable parameter and consider factors such as the intact rock strength, joint spacing, joint condition, field stress, join sets, and groundwater. The Geological Strength Index (Hoek and Brown, 1997) assesses the lithology, structure, and condition of discontinuity surfaces in the rock mass (Lin et al., 2017).

\footnotetext{
${ }^{*}$ Corresponding author: T.F. FATHANI, Department of Civil and Environmental Engineering, Gadjah Mada University. Jl. Grafika 2 Yogyakarta, Indonesia. E-mail: tfathani@ugm.ac.id
}

Rock mass is complex, heterogeneous, and difficult to see using the conventional testing. It is possible to see the rock mass by using geophysical methods.The P-wave velocity test that can be carried out both in the laboratory and on-site is a common non-destructive testing method used in civil, geotechnical, and mining projects such as underground opening, quarrying, blasting, and ripping (Yagiz, 2011). The seismic refraction technique is the oldest and the most appropriate method of investigating the rock mass properties (Sjøgren et al., 1979; Barton, 2007; Ghanbari et al., 2013). The seismic method can be used to provide an indirect assessment of the geomechanical properties of rock mass. Seismic refraction is one of the indirect methods used in determining the rock mass properties (Zhang, 2005).

P-wave velocity has a correlation with some rock properties such as uniaxial compressive strength, modulus of elasticity, Schmidt hard- 
ness, slake durability index, porosity and density (Sharma and Singh, 2008; Yagiz, 2011; Khandelwal, 2013). Based on McCann et al. (1990); McDowell (1993); El-Naqa (1996); Budetta et al. (2001); Bery and Saad (2012); Fathollahy et al. (2017); Nourani et al. (2017) $\mathrm{P}$-wave velocity has a correlation with the basic parameters of rock mechanic, namely fracture frequency and Rock Quality Designation (RQD) where the P-wave velocity decreases as the number of joints increases (Kahraman, 2001).

The correlation between P-wave velocity and rock mass properties are not constant and can be varied with rock types. This study aimed to find a correlation between the P-wave velocity and the RQD for volcanic rocks at the site of Bener Dam. This study uses RQD in the analysis because RQD is the only available information on discontinuities in routine site investigations and the only one factor that affects the deformability and strength of jointed rock masses (Zhang, 2016). The correlation is obtained by the regression analysis between the $\mathrm{P}$-wave velocity (vp) resulted from the seismic refraction test and the RQD resulted from the core drilling.

\section{Methods}

This study uses primary and secondary data. The secondary data are core drilling data and the results of the seismic testing obtained from BBWS Serayu Opak based on the work report of Geological Stabilization of Bener Dam (PT. Virama Karya et al., 2015). There are 14 boreholes and 3 seismic lines spread in the dam area, plinth area, and spillway. The seismic refraction testing in this study consists of 3 lines with the total seismic length of 1,835 meters. The vibration source used in the seismic testing is a hammer punch weight of 20 Lbs or wood which was struck on an iron plate with a diameter of $20 \mathrm{~cm}$ and a thickness of $15 \mathrm{~mm}$. The seismic refraction data obtained was seismic velocity values $\left(v_{p}\right)$ on each line which is divided into several spreads. The seismic refraction lines in the study area are scattered in several locations, they are dam site (line $A-A^{\prime}$ ) with a track length of $660 \mathrm{~m}$, plinth (B-B') with a track length of $570 \mathrm{~m}$, and spillway (D-D') with a track length of $605 \mathrm{~m}$. The seismic refraction data for each spread was correlated according to each line to obtain a seismic velocity profile.

From the borehole data, the information on subsurface lithology, groundwater depth, Rock Quality Designation (RQD), and permeability values can be obtained. The borehole data is then correlated to obtain the subsurface geological profiles. The cross section for borehole data correlation is adjusted to the seismic line as in Figure 1. The correlation section of $\mathrm{A}-\mathrm{A}^{\prime}$ is based on borehole data BH-01 (2015), BH-02 (2015), BH-03 (2015), and BH-01 (2017). The correlation section of $\mathrm{B}^{-\mathrm{B}^{\prime}}$ is based on borehole data BH-04Ki (2015), BH-04Ka (2015), BH05 (2015), BH-06 (2015), BH-10 (2015), BH-11 (2015), and BH-03 (2017). The correlation section of D-D' is based on borehole data BH-14 (2015), BH-04 (2017), and BH-05 (2017).

The lithology correlation in each cross section is compared to the P-wave velocity value to draw a comparison of the RQD values and vp values at each depth. Furthermore, a linear regression analysis is performed to determine the relationship between RQD and P-wave velocity. The linear correlation analysis describes a linear relationship between two or more variables, previously it is not yet known whether one variable is affected by other variables (Lind et al., 2006).

\section{RESUlts}

\subsection{Geological condition}

The Bener Dam plan is located in Bogowonto River. Based on the topography, the Bener Dam plan and its surroundings are hilly area which is characterized by tight contours and extending to the right and left of the river. Based on the Regional Geological Map of Yogyakarta (Rahardjo et al., 1995), as shown in Figure 2, the formations found at the study location are Kebobutak Formation (Tomk) and Alluvium Deposits (Qa). The Kebobutak Formation (Tomk) consists of andesite, tuff, lapilli tuff, agglomerates, and andesite lava, this formation is most commonly found at the location study. The Alluvium Deposit (Qa) consists of gravel, sand, silt, and clay along the large river. Stratigraphically from young to old, the lithology units found in the study location consist of river deposits, andesite lava, and pyroclastic andesite breccia. 

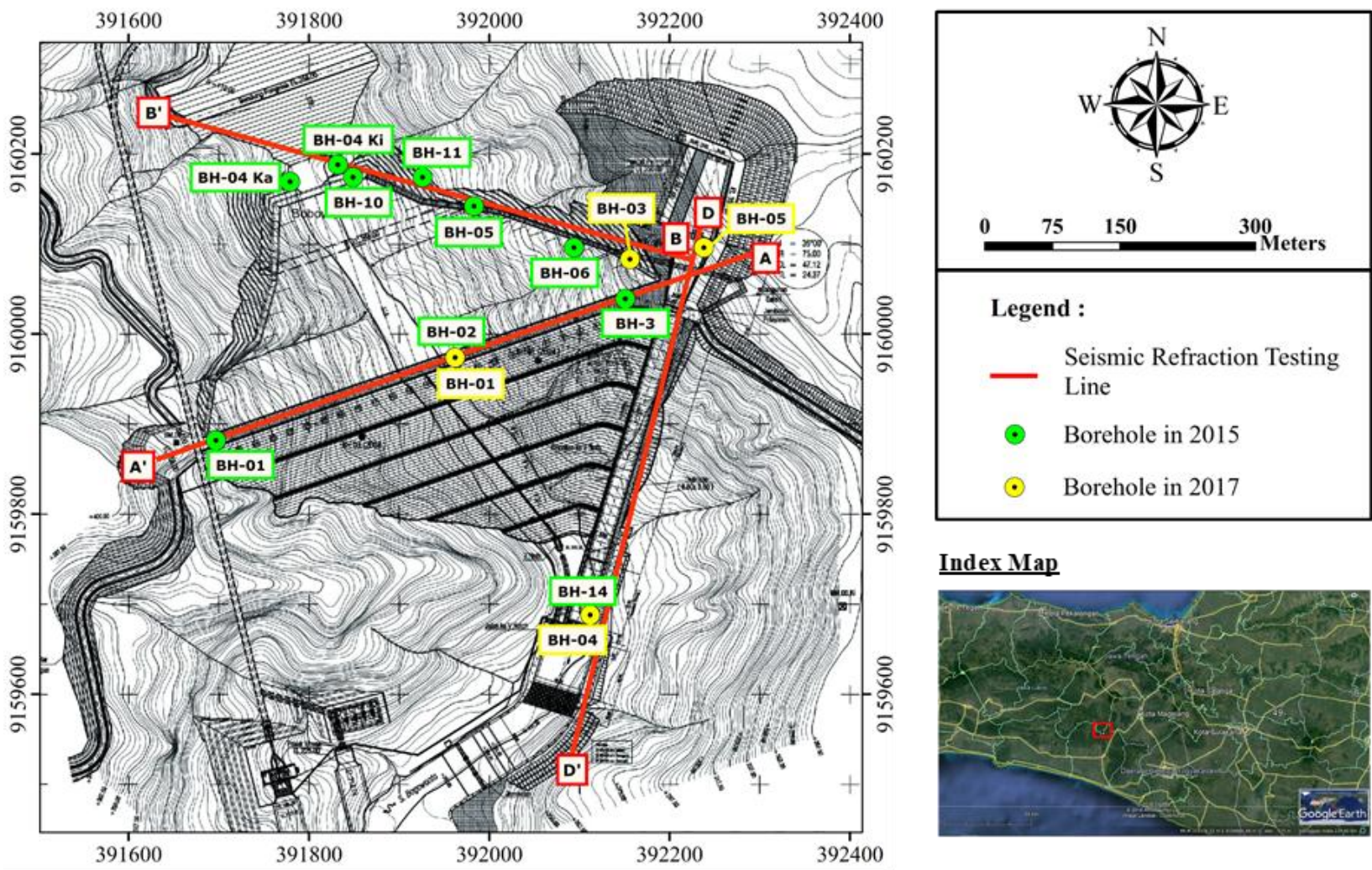

Figure 1: Location map of boreholes and seismic profiles at Bener Dam site area.
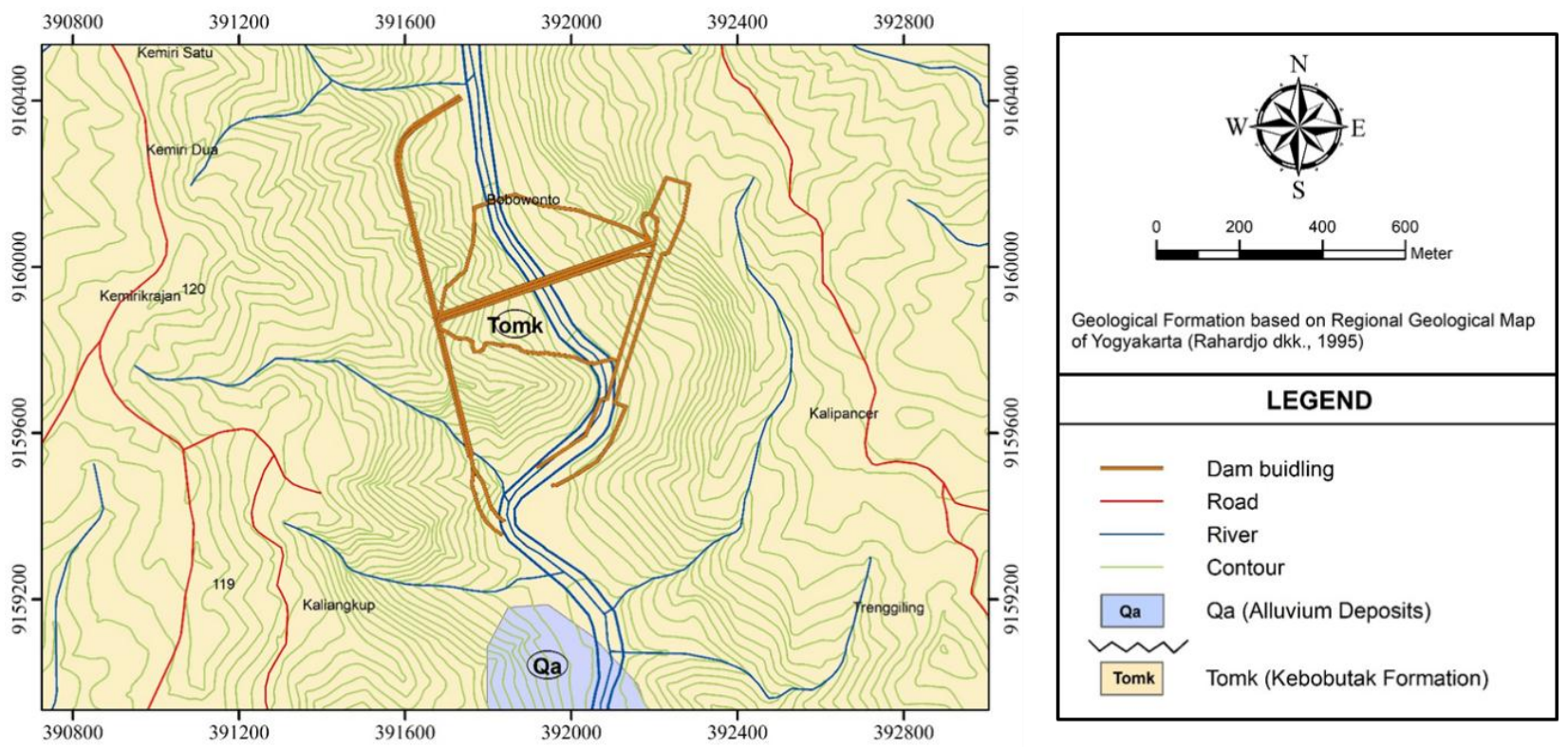

Figure 2: Geological map of the research location based on regional geological map of Yogyakarta (modified from Rahardjo et al., 1995). 
As the results of the lithology correlation to the borehole data, it can be seen that the subsurface condition in the Bener Dam plan from top to bottom consists of silty clay, river deposits, andesite breccia, tuff breccia, and tuff. Andesite breccia is the dominant lithology at the study location, the thickness of the layer reaches 80 meters and it is found at all boreholes. The results of the correlation of borehole data at the dam site as cross section A- $\mathrm{A}^{\prime}$ is shown in Figure 3, the first layer is clayey soil with a thickness of $5 \mathrm{~m}$, while in the river, there are sand and gravel deposits. The second layer is andesite breccia, and beneath it is a tuff breccia as thick as $50 \mathrm{~m}$. The last layer is tuff with a thickness of $10 \mathrm{~m}$ that is only found at borehole BH-01 (2017).

Based on the cross section B- $\mathrm{B}^{\prime}$ as shown in Figure 4, it is known that the subsurface conditions of the plinth area consist of the upper layer in the form of clayey soil, the upper layer of the river consists of sand and gravel deposits, and beneath it is andesite breccia, tuff, and tuff breccias intersection. On the left back of the plinth, a $36 \mathrm{~m}$ thick tuff layer is found. The subsurface conditions in the spillway area consist of the upper layer in the form of clay while the upper layer of the river consists of sand and gravel deposits. Beneath the clay and river deposits is andesite breccia with a thickness of $70 \mathrm{~m}$, cross section D-D' is shown in Figure 5.

\subsection{Seismic refraction results}

The seismic profiles at the dam site are represented by the line $\mathrm{A}-\mathrm{A}^{\prime}$, it indicates that at the dam site there are three layers with a different value of P-wave velocity. The first layer with thickness of $5 \mathrm{~m}$ is a layer with the P-wave velocity value between 0.24 and $0.30 \mathrm{~km} / \mathrm{s}$. Based on the borehole data, this layer is overburden soil consisting of silty clay and gravely clay. The second layer with the P-wave velocity value between 0.96 and $2.4 \mathrm{~km} / \mathrm{s}$ with layer thickness of $60 \mathrm{~m}$ is andesite breccia based on the borehole data. The third layer with the P-wave velocity value between 3.1 and $4.1 \mathrm{~km} / \mathrm{s}$, based on the borehole data, is andesite breccia. The seismic profile of the line A-A at the dam site is shown in Figure 6.

The seismic profile of line B-B' indicates that there are three layers with different $\mathrm{P}$-wave ve- locity values. The first layer with thickness of 5 meters has a value of $P$-wave velocity between 0.21 and $0.27 \mathrm{~km} / \mathrm{s}$. The second layer has Pwave velocity value between 1.0 and $1.8 \mathrm{~km} / \mathrm{s}$ with layer thickness of 23 to $32 \mathrm{~m}$. The third layer has $\mathrm{P}$-wave velocity value between 3.5 and $4.1 \mathrm{~km} / \mathrm{s}$. The seismic profile of the line $B-B^{\prime}$ at the plinth is shown in Figure 7. The seismic profile of line $\mathrm{D}-\mathrm{D}^{\prime}$ shows that there are three layers; the first layer has P-wave velocity between 0.24 and $0.27 \mathrm{~km} / \mathrm{s}$, the second between 0.9 and $1.7 \mathrm{~km} / \mathrm{s}$, and the third between 3.4 and $4.0 \mathrm{~km} / \mathrm{s}$. The seismic profile of the line D-D' at the spillway is shown in Figure 8.

\subsection{Correlation of RQD with P-wave velocity}

The results of the regression analysis of the data in line $\mathrm{A}-\mathrm{A}^{\prime}$ obtain correlation values $\mathrm{R}=0.801$ which is considered as a high relationship category, with a coefficient of determination $\mathrm{R}^{2}=$ 0.641 which is included in the high accuracy category. These results show that there is a relationship between P-wave velocity and RQD with linear regression equations $R Q D=0.023 v_{p}$ -0.885 . The regression chart of line $A-A^{\prime}$ is shown in Figure 9.

The results of the regression analysis on the line $\mathrm{B}-\mathrm{B}^{\prime}$ obtains correlation value $\mathrm{R}=0.558$ which is considered as a moderate relationship category, with the coefficient of determination $\mathrm{R}^{2}=0.311$ which is included in moderate accuracy. This shows that there is a relationship between P-wave velocity and RQD with linear regression equations $\mathrm{RQD}=0.014 v_{p}+18.612$. The regression chart of line $B-B^{\prime}$ is shown in Figure 10.

The results of the regression analysis on the line $\mathrm{D}-\mathrm{D}^{\prime}$ obtain correlation value $\mathrm{R}=0.681$ which is considered as moderate relationship, the coefficient determination $\mathrm{R}^{2}=0.464$ which is included in moderate accuracy. This shows that there is a relationship between P-wave velocity and RQD with linear regression equations $\mathrm{RQD}=0.018 v_{p}+20.579$. The regression chart of line D-D' is shown in Figure 11.

\section{DisCUSSION}

The results of the regression analysis on each of the line seismic are summarized in Table 1. Based on the analysis result, the largest coefficient correlation is obtained, that is in line 


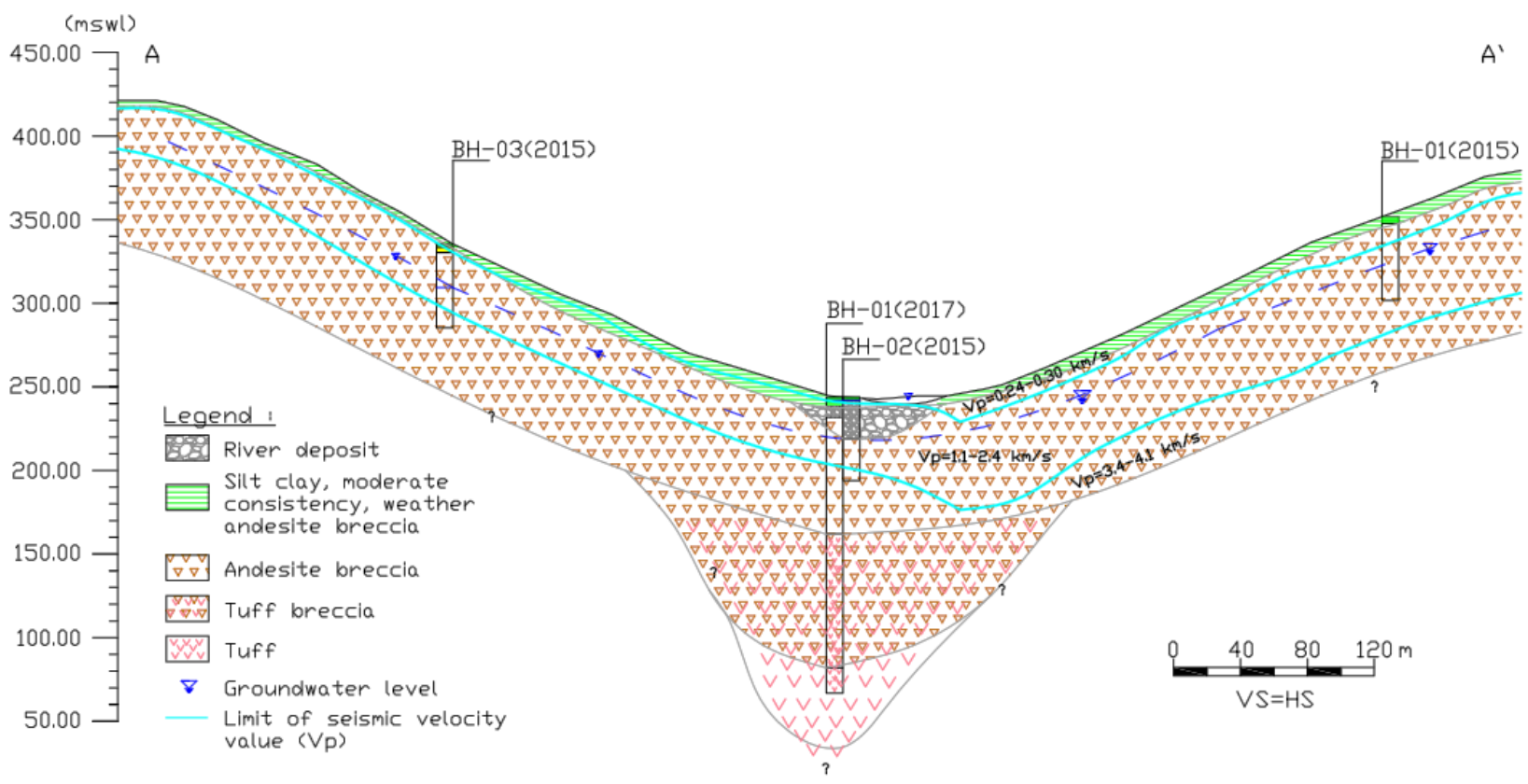

Figure 3: Geological profile of cross section $\mathrm{A}-\mathrm{A}^{\prime}$ at the dam site.

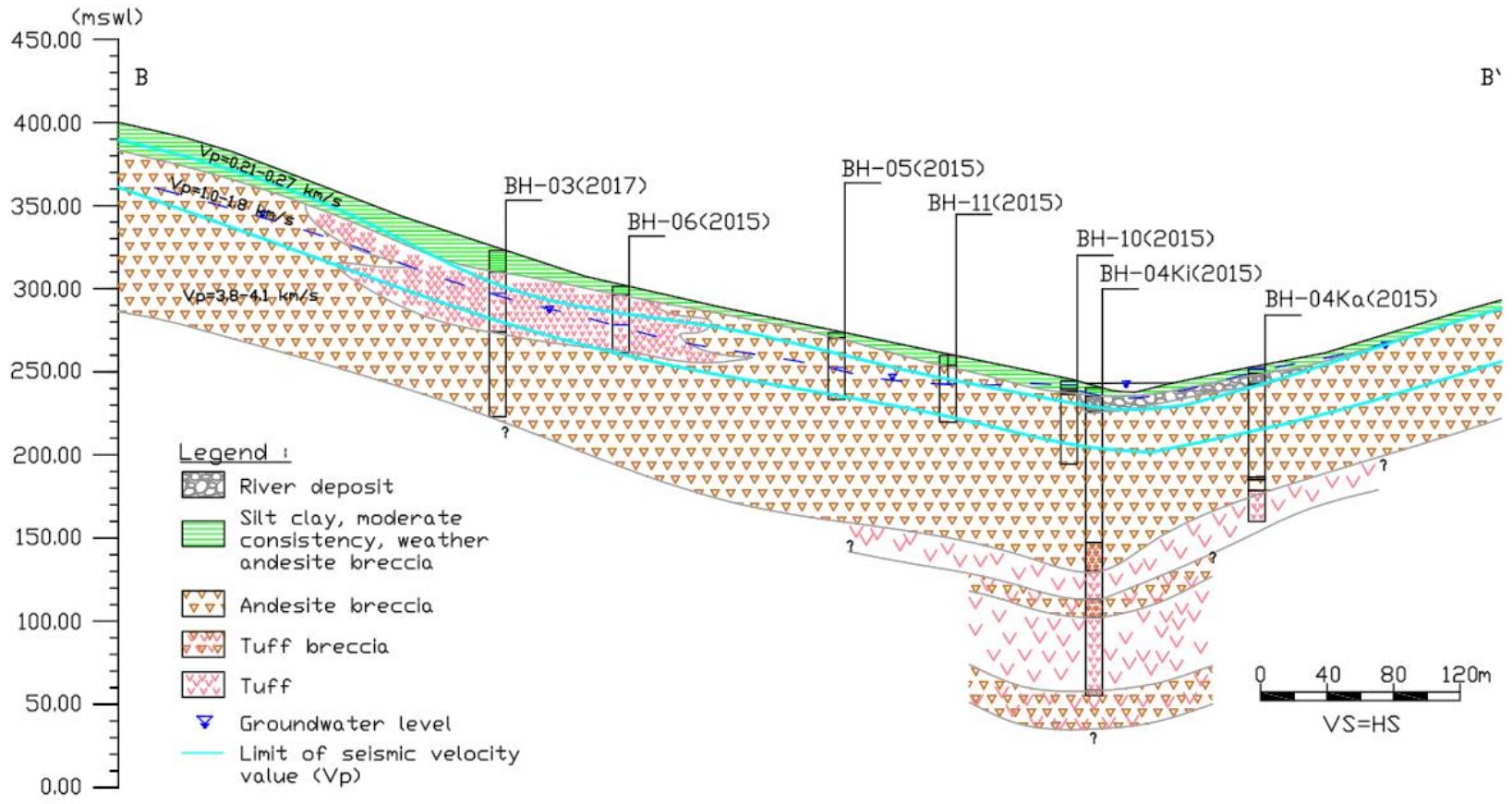

Figure 4: profile of cross section $B-B^{\prime}$ at the plinth. 


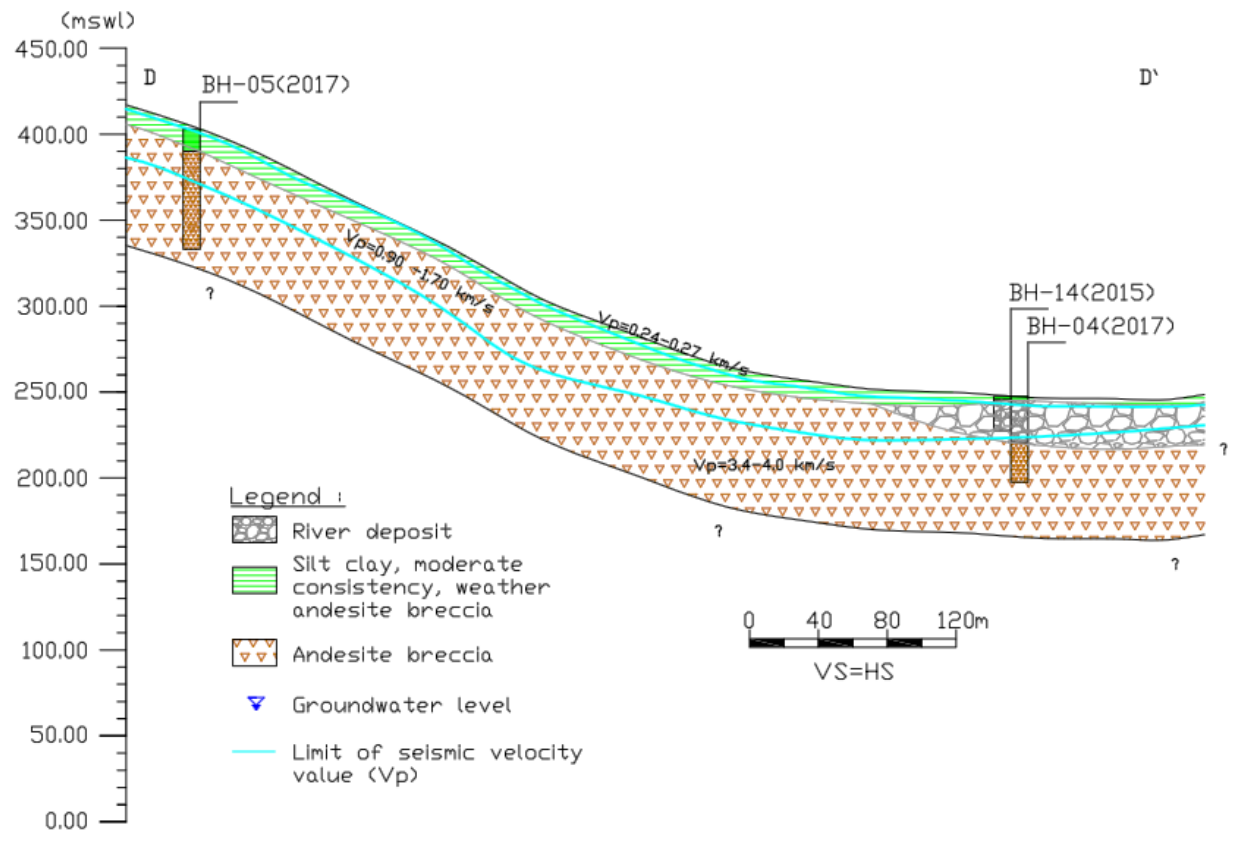

Figure 5: Geological profile of cross section D-D' at the spillway.

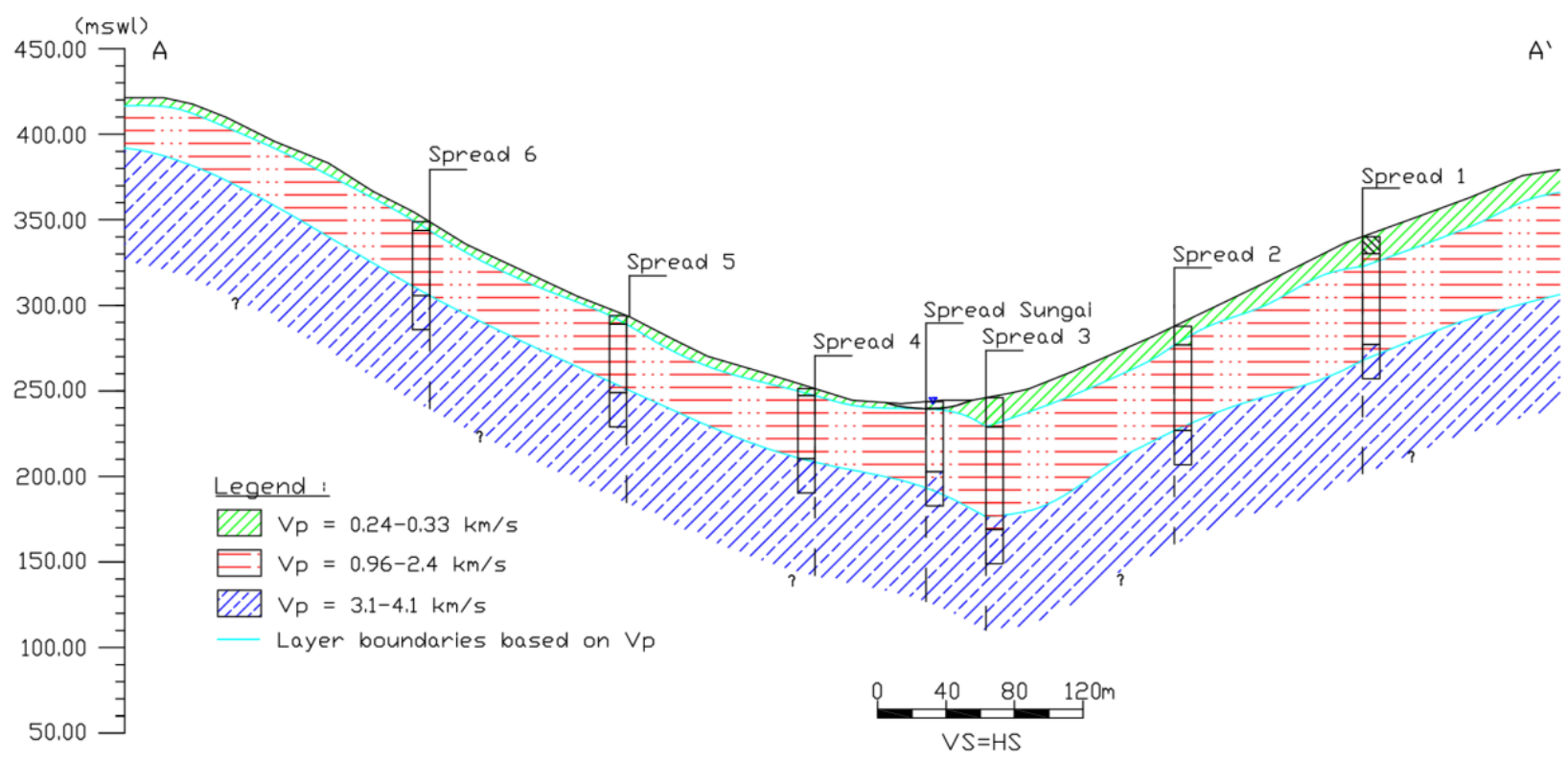

Figure 6: Seismic profile of line $\mathrm{A}-\mathrm{A}^{\prime}$ at the dam site. 
SALAAMAH et al.

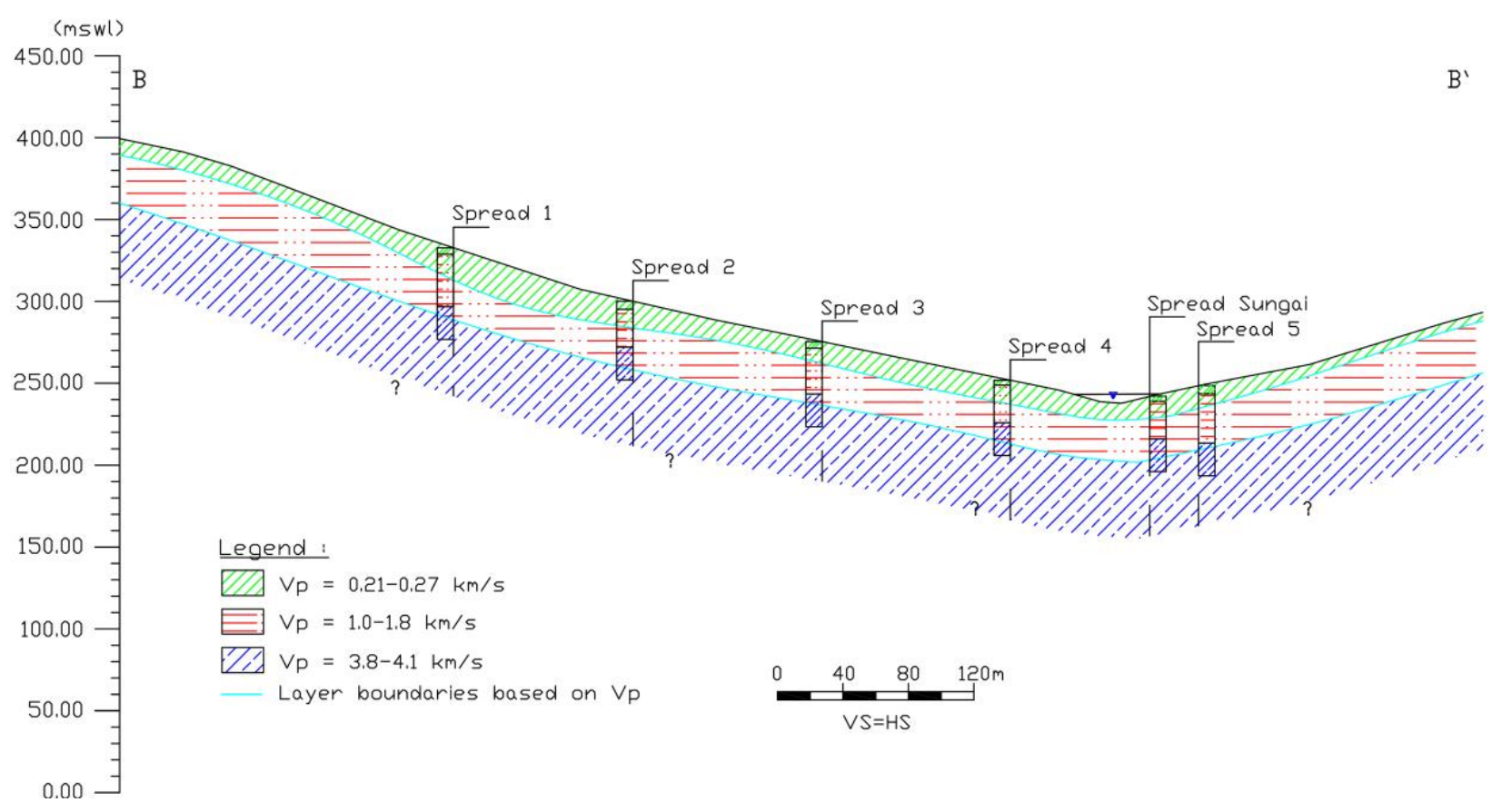

Figure 7: Seismic profile of line B-B' at the plinth.

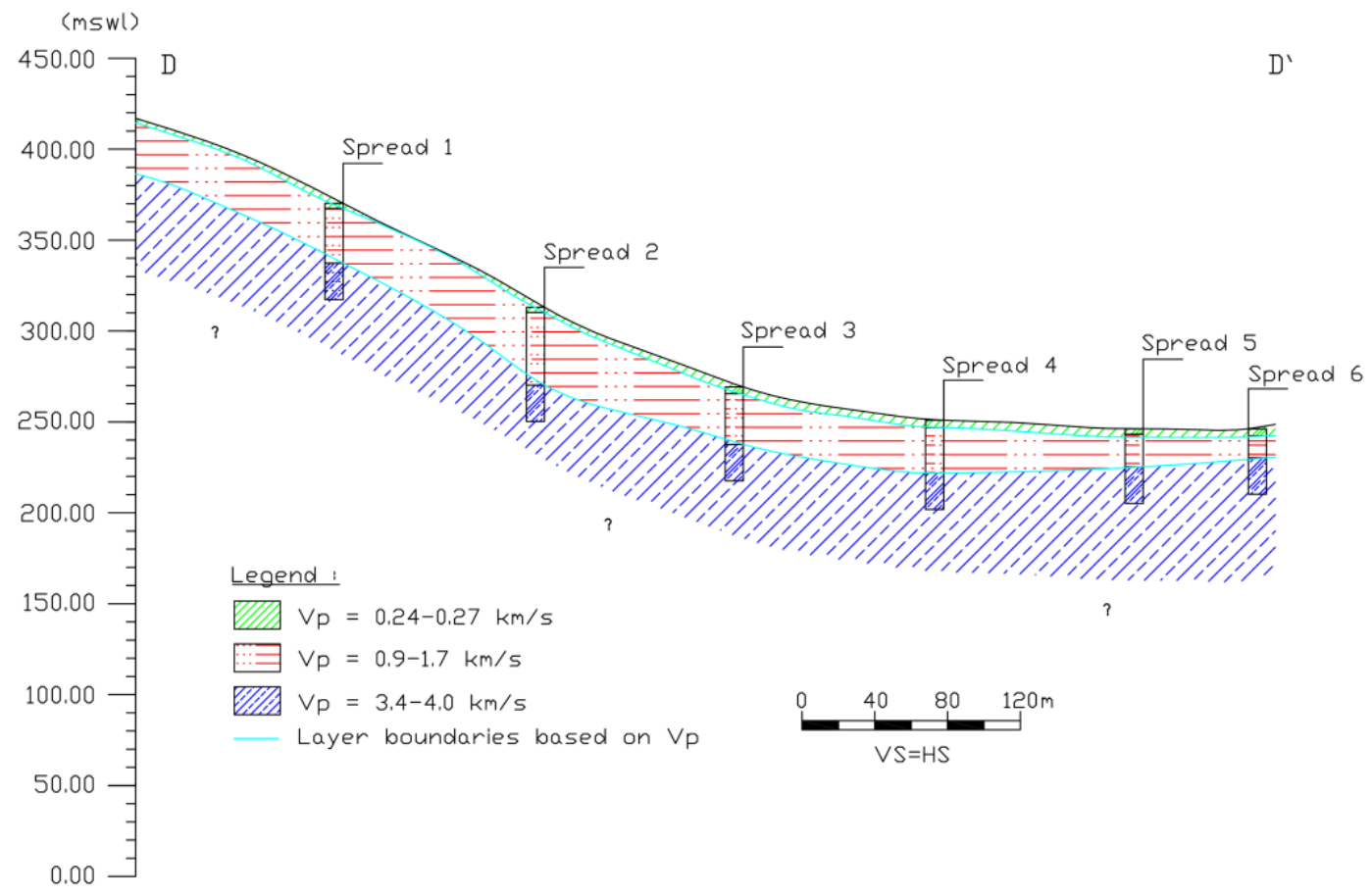

Figure 8: Seismic profile of line D-D' at the spillway. 


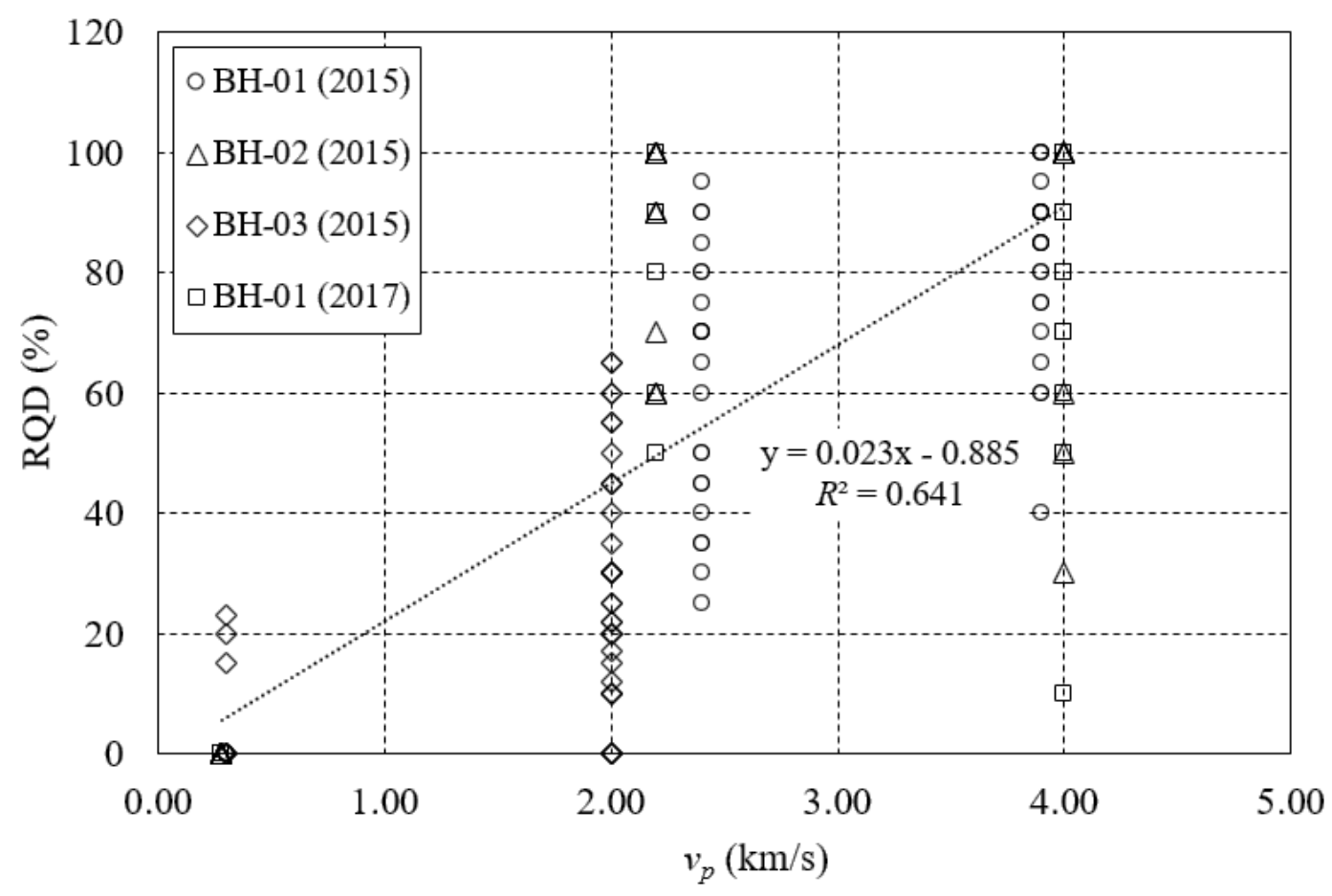

Figure 9: Regression analysis chart of line $\mathrm{A}-\mathrm{A}^{\prime}$ at the dam site.

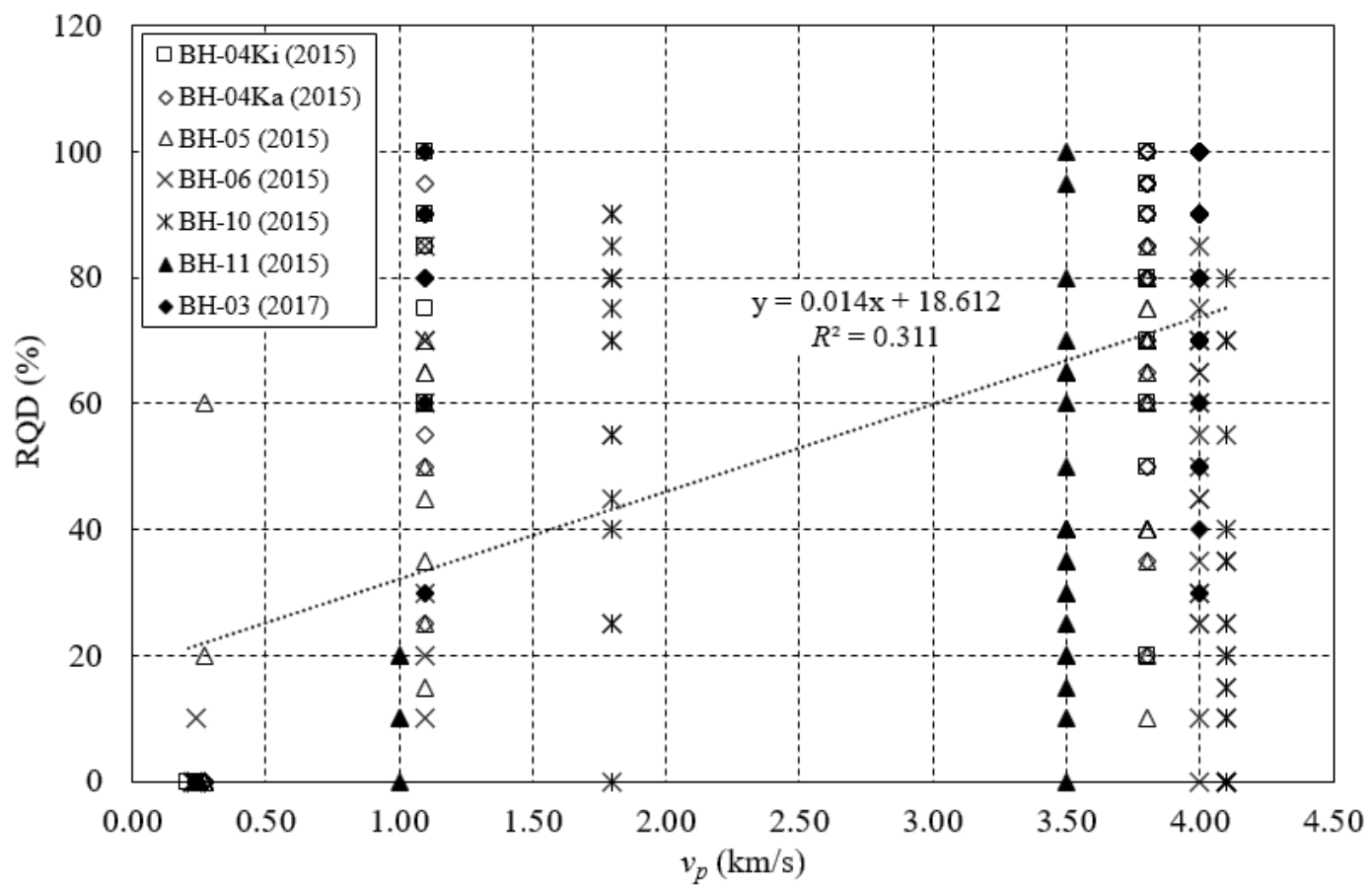

Figure 10: analysis chart of line $\mathrm{B}-\mathrm{B}^{\prime}$ at the plinth area. 


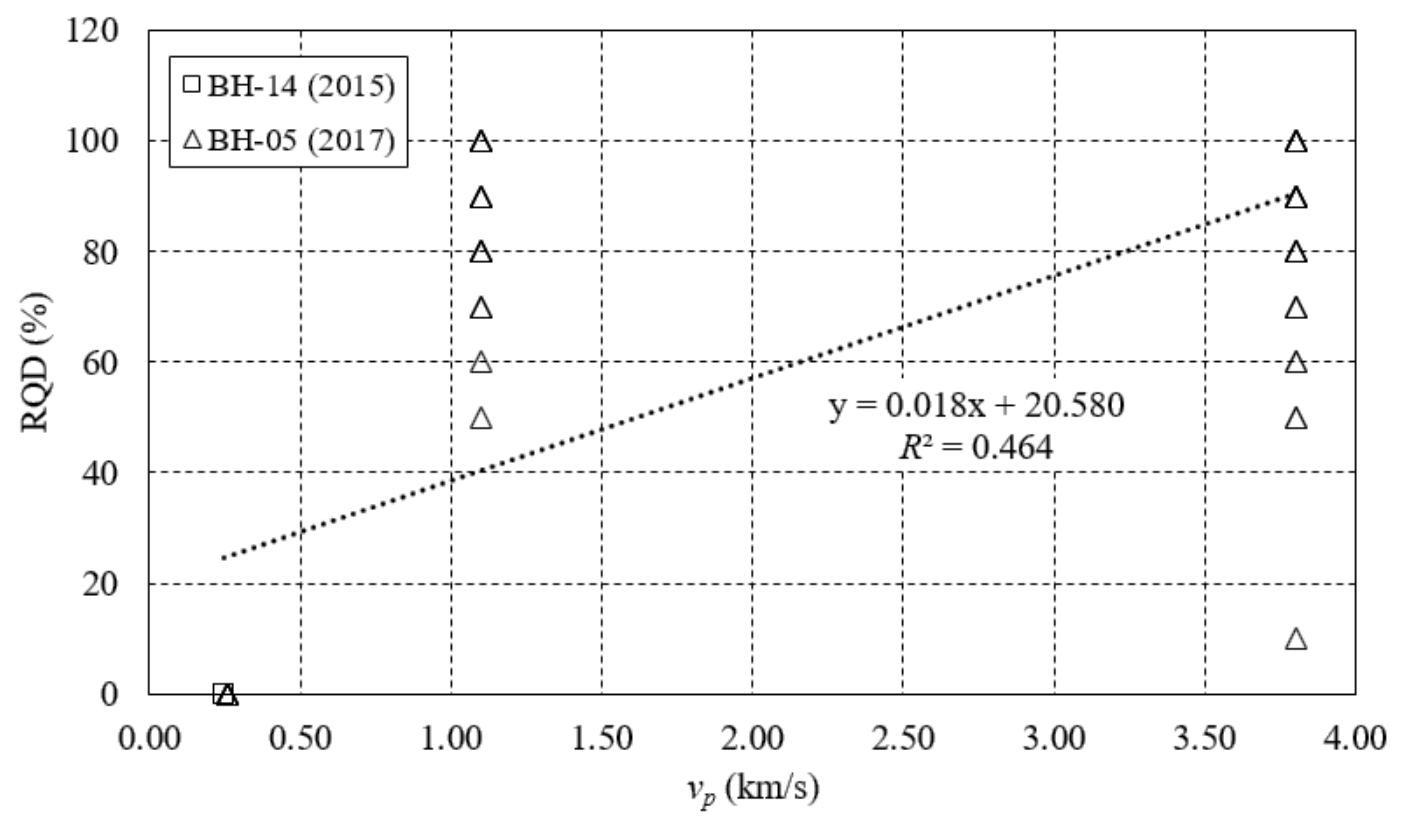

Figure 11: Regression analysis chart of line D-D' at the spillway area.

Table 1: The results of linear regression analysis.

\begin{tabular}{llc}
\hline Line seismic & Regression equation & $R$ value \\
\hline Line A-A & $\mathrm{RQD}=0.023 v_{p}-0.885$ & 0.801 \\
\hline Line $\mathrm{B}-\mathrm{B}^{\prime}$ & $\mathrm{RQD}=0.014 v_{p}-18.612$ & 0.558 \\
\hline Line $\mathrm{D}-\mathrm{D}^{\prime}$ & $\mathrm{RQD}=0.018 v_{p}-20.579$ & 0.681 \\
\hline All Lines & $\mathrm{RQD}=0.016 v_{p}-14.044$ & 0.640 \\
\hline
\end{tabular}

$\mathrm{A}-\mathrm{A}^{\prime} \mathrm{R}=0.801$, the coefficient determination $\mathrm{R}^{2}$ $=0.641$, the linear regression equation $\mathrm{RQD}=$ $0.023 v_{p}-0.885$. This shows that there is a relationship between P-wave velocity and RQD, reflecting that the value of $\mathrm{P}$-wave velocity in rocks is affected by the RQD conditions on the rock. This happens because the value of RQD depends on the fracture, the closer the distance between the fractures, the smaller the RQD value. If the distance between the fractures increases, the RQD value is greater. This fracture affects the seismic wave velocity in the rock masses. However, the decrease in the value of $\mathrm{P}$-wave velocity in the rock mass is not only due to decrease in the RQD value, but also due to other factors that affect $\mathrm{P}$-wave velocity.

The results of the data analysis from all line seismic show good results, as shown in Figure 12. Based on the regression analysis results of all data line seismic in the study location, the coefficient correlation $\mathrm{R}=0.640$ is ob- tained, showing that the P-wave velocity values and RQD have a fairly good correlation. The coefficient determination $R^{2}=0.410$ shows that the relationship between $\mathrm{P}$-wave velocity and RQD has moderate accuracy. The regression equation that shows the relationship is $\mathrm{RQD}=$ $0.016 v_{p}+14.044$. The analysis shows that the Pwave velocity value has a positive relationship with RQD conditions. This can be seen from the decreasing RQD value when the P-wave velocity value obtained from the test decreases.

The results of the analysis in each section give the same results as the research conducted by Bery and Saad (2012) where the RQD value is influenced by the value of $\mathrm{P}$-wave velocity. This is because the value of RQD depends on the fracture frequency, while the fracture frequency affects the value of $P$-wave velocity.

\section{CONCLUSION}

The results of the correlation of borehole data indicate that the subsurface conditions around the site of the Bener Dam generally consist of clayey soil, sand and gravel deposits, andesite breccia, tuff breccia, and tuff. The seismic refraction test results show that there are three layers with different $P$-wave velocity values. In general, the first layer with P-wave velocity between 0.21 and $0.33 \mathrm{~km} / \mathrm{s}$ is clayey soil, the second layer with the value of P-wave velocity between 0.90 and $2.40 \mathrm{~km} / \mathrm{s}$ is andesite breccia, 


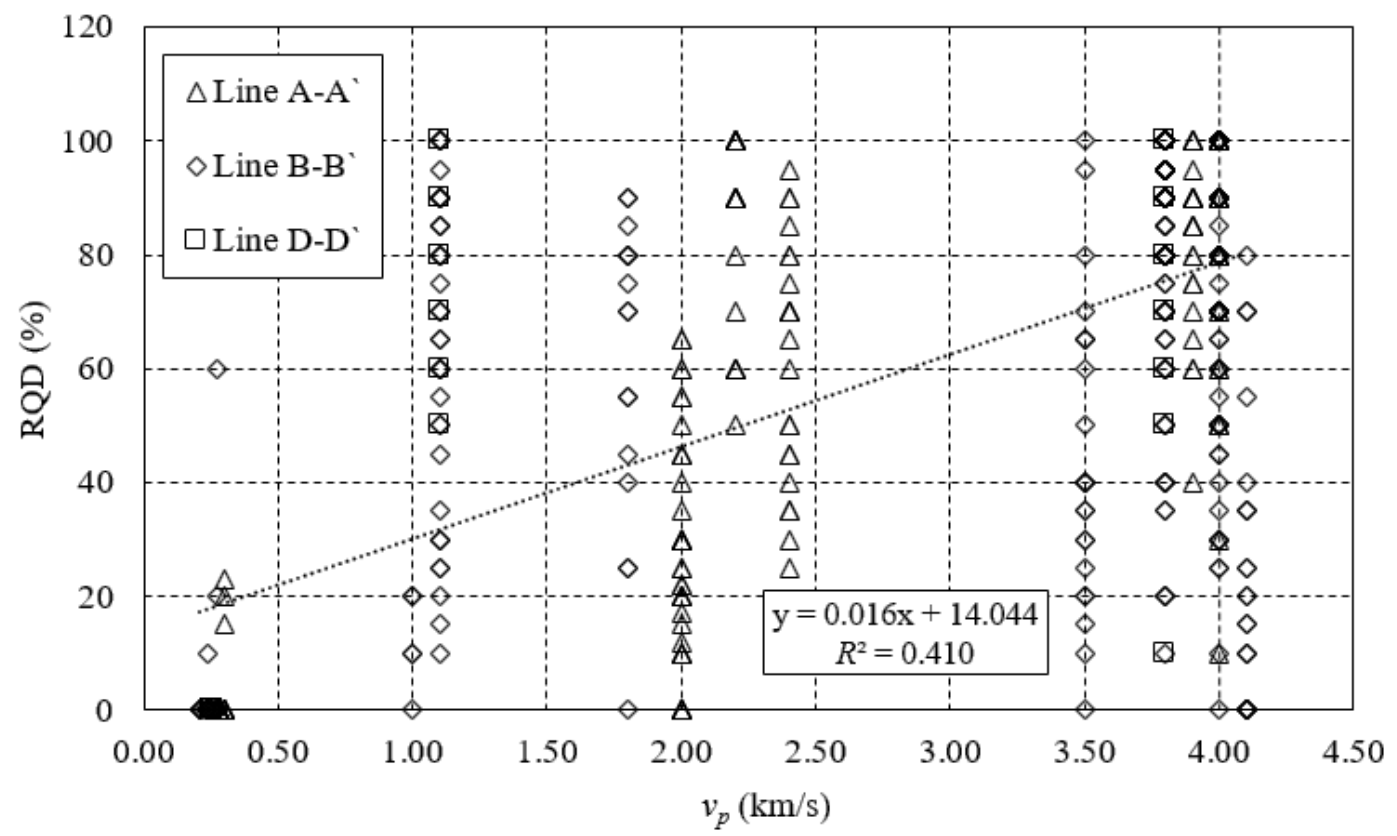

Figure 12: The regression analysis chart based on data from all line seismic.

and the third layer with the value of P-wave velocity between 3.10 and $4.10 \mathrm{~km} / \mathrm{s}$ is also a layer of andesite breccia.

The seismic refraction method is one of the indirect methods that can be used to assess the quality of rock mass on wide scale. Based on the regression analysis results of the data $\mathrm{P}$-wave velocity and RQD on each seismic line at the Bener Dam site, the highest correlation value is obtained in the line $A-A^{\prime}$ with the value $R=$ 0.801 . However, this correlation does not represent the overall data at the study site. The regression analysis results of $\mathrm{P}$-wave velocity and RQD in all seismic line data with the overall data representing the conditions in the study location obtains a fairly good correlation with the value of the coefficient correlation $R=0.640$ and the linear regression equation $\mathrm{RQD}=0.016 v_{p}+$ 14.044. This empirical equation shows the relationship between P-wave velocity and RQD. It can be applied to the basic assessment of the rock mass quality indirectly in locations with the same geological conditions.

\section{ACKNOWLEDGEMENTS}

The authors would like to express their gratitude to River Basin Research Station of Serayu Opak, Wahana Krida Konsulindo Inc., Soil Mechanics Laboratory of Civil and Environmental Engineering Department of Universitas Gad- jah Mada, and Central Laboratory of Geological Engineering Department of Universitas Gadjah Mada, which have supported this research.

\section{REFERENCES}

Barton, N. (2007) Rock Quality, Seismic Velocity, Attenuation and Anisotropy. Netherlands: Taylor \& Francis.

Barton, N., Lien, R. and Lunde, J. (1974) Engineering Classification of Rock Masses for the Design of Tunnel Support. Rock Mechanics, 6, pp.189-236.

Bery, A.A. and Saad, R. (2012) Correlation of Seismic P-Wave Velocities with Engineering Parameters (N Value and Rock Quality) for Tropical Environmental Study. International Journal of Geoscience, 3, pp.749-757.

Bieniawski, Z.T. (1989) Engineering Rock Mass Classifications: A Complete Manual for Engineers and Geologists in Mining, Civil and Petroleum Engineering. Canada: Wiley.

Budetta, P., De Riso, R. and De Luca, C. (2001) Correlations Between Jointing and Seismic Velocities in Highly Fractured Rock Masses. Bulletin of Engineering Geology and the Environment, 60(3), pp.185-192.

Deere, D.U., Hendron, A.J., Patton, F.D. and Cording, E.J. (1967) Design of Surface and Near Surface Construction in Rock. In Failure and Breakage of Rock. Proceedings of 8th US Symposium Rock Mechanics, Society of Mining Engineers, American Institute of Mining, Metallurgical and Petroleum Engineers (SAUS), 1(1), pp. 237-302.

El-Naqa, A. (1996) Assessment of Geomechanical Characterization of A Rock Mass Using a Seismic 
Geophysical Technique. Geotechnical and Geological Engineering, pp. 291-305.

Fathollahy, M., Uromeiehy, A. and Riahi, M.A. (2017) Evaluation of P- wave velocity in Different Joint Spacing. 58, pp. 157-168.

Ghanbari, Y., Ramazi, H., Pazand, K. and Madani, N. (2013) Investigation of Rock Quality of Shirinrud Dam Site by Engineering Seismology. Arabian Journal of Geosciences, 6, pp.177-185.

Hoek, E. and Brown, E.T. (1997) Practical Estimates of Rock Mass Strength. International Journal of Rock Mechanics and Mining Sciences, 34(8), pp. 1165-1186.

Kahraman, S. (2001) A Correlation Between P-wave Velocity, Number of Joints and Schmidt Hammer Rebound Number. International Journal of Rock Mechanics and Mining Sciences, 38(5), pp.729-733.

Khandelwal, M. (2013) Correlating P-wave Velocity with the Physico-Mechanical Properties of Different Rocks. Pure and Applied Geophysics, 170(4), pp. 507-514.

Lin, D., Lou, F., Yuan, R., Shang, Y., Zhao, Y., Ma, J. and Zhang, L. (2017) Rock Mass Characterization for Shallow Granite by Integrating Rock Core Indices and Seismic Velocity. International Journal of Rock Mechanics and Mining Sciences, 93, pp. 130-137.

Lind, D.A., Marchal, W.G. and Wathen, S.A. (2006) Basic Stastistic for Bussiness and Economics. Singapore.

McCann, D.M., Culshaw, M.G. and Northmore, K.J. (1990) Rock Mass Assessment from Seismic Measurements. Geological Society Engineering Geology Special Publication, pp. 257-266.
McDowell, P.W. (1993) Seismic Investigation for Rock Engineering. Rock Testing and Site Characterization, pp. 619-634.

Nourani, M.H., Moghadder, M.T. and Safari, M. (2017) Classification and Assessment of Rock Mass Parameters in Choghart Iron Mine Using P-wave Velocity. Journal of Rock Mechanics and Geotechnical Engineering, 9, pp. 318-328.

PT. Virama Karya, PT. Yodya Karya and PT. Wahana Krida Konsulindo, 2015. Pemantapan Geologi Bendungan Bener. Yogyakarta.

Rahardjo, W., Sukandarrumidi and Rosidi, H.M.D. (1995) Peta Geologi Regional Lembar Yogyakarta Skala 1:100.000. Bandung: Geology Research and Development Center.

Sharma, P.K. and Singh, T.N. (2008) A correlation between P-wave velocity, impact strength index, slake durability index and uniaxial compressive strength. Bulletin of Engineering Geology and the Environment, 67(1), pp. 17-22.

Sjøgren, B., Øfthus, A. and Sandberg, J. (1979) Seismic Classification of Rock Mass Qualities. Geophysical Prospecting, 27, pp. 409-442.

Yagiz, S. (2011) P-wave Velocity Test for Assessment of Geotechnical Properties of Some Rock Materials. Bull. Mater. Sci., 34(4), pp. 947-953.

Zhang, L. (2005) Engineering Properties of Rock. USA: Elsevier.

Zhang, L. (2016) Determination and Applications of Rock Quality Designation (RQD). Journal of Rock Mechanics and Geotechnical Engineering, 8, pp. 389-397. 